УДК 355.4:[930.1+32.019.51](470+571+477)

ХАРДЕЛЬ Р.3.

https://orcid.org/ 0000-0002-2243-9722

https://doi.org/10.33577/2313-5603.36.2021.231-244

\title{
ІСТОРИЧНА ПОЛІТИКА РОСІЙСЬКОЇ ФЕДЕРАЦЇ ЯК ЗАГРОЗА НАЦІОНАЛЬНІЙ БЕЗПЕЦІ УКРАЇНИ
}

У статті аналізується процес формування та сутність історичної політики, яку провадить владна еліта сучасної РФ, методи ії реалізації, ключові ознаки. Характеризуються інструменти та засоби, що використовуються задля ії практичної реалізації в умовах тоталітарного суспільства. Розкрито сутність поняття «історична політика» та їі основні характеристики. Зазначено ризики та небезпеки які містить їі провадження у РФ на державному рівні як для російського суспільства так і для національної безпеки України. Описано діючі методики формування суспільної свідомості за розробленими владою шаблонами з метою досягнення політичних цілей та використання історії для обгрунтування агресивної зовнішньої політики РФ.

Ключові слова: Національна безпека, історична політика, політика пам'яті, історична свідомість.

Постановка проблеми та стан ї̈ дослідження. Поняття національної безпеки України визначено у Законі України «Про національну безпеку України» як «захищеність державного суверенітету, територіальної цілісності, демократичного конституційного ладу та інших національних інтересів України від реальних та потенційних загроз» (Про нащіональну безпеку України, 2018). Актуальні загрози національній безпеці та механізми захисту національних інтересів України визначає такий рамковий нормативно-правовий акт, як «Стратегія національної безпеки», що виступає основою для планування та реалізації державної політики у сфері національної безпеки. У діючій редакції «Стратегії національної безпеки України», яку було затверджено Указом Президента України у вересні 2020 року, Російську Федерацію (далі - РФ) визначено у якості держави-агресора, що виступає джерелом довгострокових системних загроз національній безпеці України, при цьому однією із актуальних загроз

Хардель Роман Збігньович, адюнкт науково-організаційного відділу, Національна академія сухопутних військ імені гетьмана Петра Сагайдачного, м. Львів.

(С) Хардель Р. 3., 2021 
національній безпеці України визначено те, що «деструктивна пропаганда як ззовні, так і всередині України, використовуючи суспільні протиріччя, розпалює ворожнечу, провокує конфлікти, підриває суспільну єдність» (Про рішення Ради нащіональної безпеки і оборони України..., 2020). Одним із найбільш ефективних та небезпечних методів, які використовує РФ у ході ведення такої деструктивної пропаганди є вплив на історичну свідомість як складову частину суспільної свідомості як власних громадян, так і громадян України, та також світової спільноти. Задля реалізації такого завдання у РФ вироблена, сформульована та реалізується вкрай жорстка історична політика.

А. Ассман, видатна німецька історикиня, трактує концепт «політика пам'яті» у якості репрезентації історичних подій 3 метою маніпулювання суспільною свідомістю у спосіб побудови історичної політики як складової частини державної ідеології. Такі дії реалізуються у формуванні історичного орієнтиру, на базі якого формується відповідна ідеологія та включають наступні етапи:

- збір уявлень про минуле;

- інтерпретація зібраного матеріалу;

- відтворення трансформованих необхідним чином уявлень про минуле у інформаційному просторі (Ассман, 2014:22).

Аналіз історичної політики, розкриття іiі мети, цілей та завдань, а також основних методів іiі реалізації у сучасному геополітичному контексті є одним з першочергових завдань щодо забезпечення національної безпеки України в умовах триваючої гібридної війни, у ході якої РФ системно застосовує політичні, економічні, інформаційно-психологічні, кібер- і воєнні засоби.

Mema cmammi - провести аналіз історичної політики, яка реалізується у РФ, та методів ії використання у гібридній війні проти України.

Аналіз останніх досліджень і публікацій. Феномен історичної політики аналізується науковою спільнотою відносно недавно, підходи до його розуміння істотно різняться, а цілі та засоби, що використовуються для їх досягнення, не завжди відкрито декларуються для широкого загалу. Уперше термін «історична політика» (Geschichtspolitik) виник у ФРН у ході так званої 
суперечки істориків (Historikerstreit) 1986 - 1987 pp. щодо причин виникнення нацизму та ступеня відповідальності німецького народу за його злочини. У тодішньому німецькому суспільстві ідеї М. Штюрмера, Е. Нольте та безпосередньо канцлера ФРН Г. Коля щодо побудови «нового патріотизму» на основі німецької історії, з якої необхідно вилучити «відчуття провини» за злочини нацизму, а натомість орієнтуватися на епізоди, якими можна й необхідно пишатися - ці ідеї не отримали повної підтримки як у суспільстві, так і в політичній та історичній спільнотах Німеччини.

Спробам форматування історії за політичними мотивами один 3 визнаних інтелектуальних лідерів німецької нації Ю. Хабермас протиставив проєкт постнаціонального «конституційного патріотизму», що грунтувався на універсальних цінностях людства та демократії (Васильченко, 2017). Хоча власне механізм формування та реалізації історичної політики таким чином у тодішній Німеччині не був реалізований - відповідний термін, однак, відтоді увійшов у науковий дискурс.

У свою чергу, в Польщі у середині 2000-х років правоконсервативні політики та прихильні до них представники суспільної думки використали апробований та негативно сприйнятий у Німеччині термін для формування «нової історичної політики», змістом якої стала відмова від «критичного патріотизму» та повернення до неоконсервативної ідеології «патріотизму завтрашнього дня» шляхом створення національного патріотизму за допомогою історії і недопущення негативного трактування польської історії як у польському суспільстві, так і за кордоном. Для реалізації цієї стратегії була створена розгалужена науковоосвітня структура, центром якої став Інститут національної пам'яті Польщі - науково-дослідний інститут із функціями слідства, обвинувачення та люстрації (Траба, 2012).

На жаль, історична політика сучасної Польщі спрямована у тому числі й на Україну. У стосунках Польщі з Україною присутня вимога скоригувати історичний наратив у відповідності до польського розуміння неоднозначних історичних питань. Таким чином, влада Польщі використовує історичну політику як засіб об'єднання власної національної спільноти та мобілізації 
електорату (Сучасна історична політика Польщі..., 2017). Однак, роль Польщі у сучасному інформаційному глобальному інформаційному протистоянні, у тому числі проти України, виходить за рамки даної роботи i, очевидно, потребує окремого дослідження.

В українській науковій спільноті питання історичної політики та політики пам'яті досить глибоко досліджені завдяки роботам В. Расевича, В. Бондара, А. Киридон, Г. Касьянова та багатьох інших. Знаковою з цього питання $є$ аналітична доповідь колективу дослідників «Політика історичної пам’яті в контексті національної безпеки України», що видана у Національному інституті стратегічних досліджень у 2019 році. Оскільки питання політики пам'яті, національної пам'яті, історичної політики, історичної пам'яті відносяться як до історії, так і до політології, соціології та інших галузей науки, надзвичайно цінною є названа спільна робота колективу вчених, серед яких наявні історики, політологи, фахівці з державного управління, політології та філософії (Yablonsky, Lozovy, Valevsky, Zdioruk, Zubchenko, Ishchenko, Karpenko, Litvinenko, Stepyko, Tokman and Chernenko, 2019).

За визначенням українського історика Г. Касьянова, «історична політика - це різновид політики, ціллю та змістом якої є цілеспрямоване конструювання та утилітарне використання у політичних цілях «історичної пам'яті» та інших форм колективних уявлень про минуле та його репрезентацій, у тому числі професійної історіографії. Історична політика здійснюється в інтересах політичних, культурних, етнічних та інших суспільних груп у боротьбі за владу, іiі втримання та перерозподіл. Історична політика $є$ засобом забезпечення політичної, культурної або інших форм лояльності великих суспільних груп, а також втримання ідеологічного та політичного контролю над ними».

Найважливішою рисою історичної політики Г. Касьянов вважає утилітарне використання історії у внутрішній політиці, юридичних та законодавчих практиках, ідеологічних, дипломатичних та військових конфліктах (Касьянов, 2019:18-19).

Погоджуємося 3 А. Міллером, що в ідеологічному плані історична політика РФ характеризується наступними ознаками:

1. Історія та пам'ять оголошуються ареною політичної боротьби із зовнішнім та внутрішнім противником. У свою чергу, 
наукова діяльність істориків перетворюється на елемент національної безпеки і підпадає під контроль з боку політичних та владних акторів.

2. Утилітарне використання історії оголошується загальною нормою, чим пояснюється порушення принципів діяльності суспільних наук, прийнятих у демократичних суспільствах.

3. За аксіому береться намагання зовнішніх противників затвердити невигідну, шкідливу для суспільства версію минулого (версія А). Таким чином, очевидною видається необхідність протистояння таким спробам шляхом просування, відстоювання протилежної інтерпретації (версія В), а фахівці, схильні до прийняття версії А, оголошуються посібниками ворога.

4. «Недостатній патріотизм» суспільства та неприйнятий 3 точки зору державного історичного наративу формат викладання історії у закладах освіти видаються за підставу історичної політики влади (Миллер, 2009:11-13).

Виклад основного матеріалу. Необхідність здійснення контролю над історичною свідомістю як власного народу, так і інших народів, у якості фактора національної безпеки закріплений у законодавстві РФ на найвищому рівні. Так, у ч.3 ст. 67.1 Конституції РФ (із поправками, прийнятими у березні 2020 року) визначено: «РФ шанує пам'ять захисників Вітчизни, забезпечує захист історичної правди. Зменшення значення подвигу народу при захисті Вітчизни не допускається». Крім цього, у ч.2 цієї ж статті визначено: «РФ, об'єднана тисячорічною історією, зберігаючи пам'ять предків... а також спадкоємність у розвитку Російської держави, визнає державну єдність, що склалася історично» (Конституция Российской Федераџии, 1993).

Тобто, в Основному законі, якому не можуть суперечити жодні нормативно-правові акти та який має найвищу юридичну силу у РФ, чітко та однозначно зафіксована монополія російської держави на «історичну правду», під якою очевидно розуміється право на єдине вірне трактування історії як на території РФ, так i за іiі межами, а також захист цього права усіма доступними засобами.

Крім цього, на рівні найвищого закону у РФ закріплений «подвиг народу при захисті Вітчизни», а будь-які сумніви у героїчних діях під час війн та протистоянь, у яких брала участь 
«тисячорічна російська держава» - від військових походів руських князів на Візантійську імперію до Російської збройної агресії проти України із 2014 р. та збройному втручанню Росії у громадянську війну в Сирії із 2015 р., суперечать Основному закону РФ та «не допускаються».

Прослідковується тотальний контроль з боку владних структур за процесом формування історичної політики, при цьому фільтрацію успішно проходить та включається до історичного наративу лише таке трактування минулого, яке повністю відповідає наперед заданим установкам. Тобто історія у РФ виступає не у якості усвідомлення та відтворення минулого у наш час, а у якості рефлексії у минуле певного уявного, бажаного майбутнього, яке повністю відповідає як очікуванням, так і вимогам владних політичних акторів (Рубизова, 2017:451).

Таким чином, на думку російського дослідника А.Міллера, історія і пам'ять використовуються як простір, і одночасно засіб. При цьому без достатнього обгрунтування як доконаний факт декларується всезагальний спосіб маніпулювання історією у цілому, на кшалт «усі так роблять - отже, це нормально», що нібито виправдовує маніпуляції у галузі історії (як публічної, так і академічної). Таким чином, політична боротьба переходить у протистояння в історичній спільноті, у ході якого відбувається підміна об'єкта дискусії на суб'єкт приналежності, внаслідок чого конкуренція, боротьба суб'єктів (політичних акторів) до яких «належать» історики замінює конкуренцію поглядів на історію, яка покликана якомога точніше встановити істину. Як аргумент провадження такої історичної політики також використовується нібито «жахливий стан патріотизму та викладання історії у школі», у крайній позиції якого історія як дисципліна виступає у якості колективної пам'яті, що транслюється через інститути освіти (Миллер, 2012: 19-23).

У якості інструменту історичної політики успішно використовуються не лише тотально керовані владою політичні актори, а безпосередньо виступи політичних лідерів. Детальний аналіз проведених досліджень виступів Президента РФ свідчить про те, що головною метою відсилання до минулого у виступах Президентів РФ є легітимізація тих чи інших дій влади, політичного курсу у цілому, а також демонстрація «генеральної 
лінії» влади у сфері історичної політики (Малинова, 2012: 368369). Окреме місце займають матеріали зустрічей російських лідерів із представниками історичної спільноти. У рамках таких діалогів як В. Путін, так і Д. Медвєдєв, неодноразово декларували, що діюча російська влада, на відміну від радянської, підтримує незалежність та об'єктивність історичної науки. Однак насправді такі зустрічі із представниками професійної спільноти використовувалися для постановки їм конкретних завдань, які змінювалися у відповідності до політичної обстановки.

Таким чином, для російської історичної спільноти на найвищому політичному рівні визначається завдання щодо легітимації діючого режиму, спротиву іншим спробам «перекодувати суспільство» крім спроб діючої влади, та іншій політиці «переписування історії під чиїсь геополітичні інтереси», крім політики російської влади (Малинова, 2019: 118).

Також важливо, що вплив російської політики на викладання історії у системі освіти не обмежується територією РФ. Так, в рамках проєкту Спільної комісії по вивченню новітньої історії російсько-німецьких відносин протягом 2014 - 2020 років було видано російсько-німецький підручник історії «Росія-Німеччина. Віхи спільної історії у колективній пам'яті» в трьох томах російською та німецькою мовами, призначений для вчителів, учнів, студентів та інших учасників освітнього процесу. У 2012 р., за часів Міністра освіти, науки, молоді та спорту України Д. Табачника, було видано першу частину спільного російськоукраїнського посібника для вчителів середньої школи Росії та України (російською мовою) під назвою «Россия и Украина на перекрёстках истории» (Россия и Украина на перекрестках истории, 2012). За висновком А. Агафонова, публікація цього і подібних видань дозволить будувати українську ідентичність таким чином, щоби вона містила «загальноросійський культурносвітоглядний компонент» у якості іi органічної частини, що, у свою чергу, реанімувало б традиції побудови «спільної Російської імперії», або, говорячи сучасною мовою - наддержави (Агафонов, 2014: 14-20). Проєкти аналогічних спільних підручників російсько-польського, російсько-білоруського, російськоавстрійського знаходяться у стадії реалізації. 
Указом Президента РФ Д. Медведєва від 15 травня 2009 p. № 549 було створено Комісію при Президентові РФ по протидії спробам фальсифікації історії на шкоду інтересам Росії. Очолив дану комісію С. Наришкін, на той час керівник Адміністрації Президента РФ, до складу комісії у тому числі увійшли заступник Міністра освіти та науки РФ, заступник Міністра юстиції РФ, керівник Росархіву, заступник Міністра культури РФ, заступник директора Федеральної служби 3 технічного та експертного контролю - відповідальний секретар Міжвідомчої комісії із захисту державної таємниці, генеральний директор Всеросійської державної телевізійної і радіомовної компанії, начальник Служби зовнішньої розвідки РФ, начальник Генерального штабу - перший заступник Міністра оборони РФ, президент Фонду вивчення історичної перспективи, заступник керівника Росдруку, заступник Секретаря Ради Безпеки РФ, заступник Міністра закордонних справ РФ, начальник управління Федеральної служби безпеки РФ, директор Інституту загальної історії РАН (О Комиссии при Президенте Российской Федераиии..., 2009). Професійні історики у складі комісії були практично відсутні.

У рамках діяльності Комісії керівникам наукових установ Відділення історико-філологічних наук Російської Академії наук (ВІФН РАН) було розіслано циркуляр від 23 червня 2009 року за підписом керівника секції історії ВІФН РАН академіка В. Тішкова, у якому було визначено завдання щодо пошуку джерел фальсифікації історії. У даному документі вимагалося подати анотований перелік історико-культурних фальсифікацій із вказанням основних джерел, осіб чи організацій, які формують та розповсюджують фальсифікацію, а також визначити потенційну небезпеку даної фальсифікації інтересам Росії та надати попередні пропозиції щодо наукового спростування фальсифікації. Також було визначено завдання надати інформацію про діяльність вчених наукової установи щодо викриття фальсифікацій та історико-культурних концепцій, які завдають шкоди інтересам Росії (Руководителям учреждений ОИФН РАН, 2009).

Характерними для історичної політики є спроби регулювання питань історії на законодавчому рівні. За словами В. Мединського, 
голови Російського військово-історичного товариства та на той час Міністра культури РФ, «псевдоісторичний абсурд, заражений ідеологічним вірусом, якщо його вчасно не зупинити, має властивість поширюватись. Приклад? Будь ласка, - «історія України» (Мединский, 2018). Кожне трактування історії, що не відповідає історичній політиці уряду РФ, визначається у суспільному дискурсі як «псевдоісторичний абсурд». Зупиняється його поширення у тому числі й законодавчими методами. За матеріалами дослідження, проведеного у 2018 р. Міжнародною правозахисною групою Агора (об'єднання юристів-правозахисників, призначенням якого є захист громадян від незаконних дій державних органів), інтерпретація та оцінка історичних подій загрожує російським дослідникам переслідуванням та кримінальною або адміністративною відповідальністю. Обмеження оцінок історичних подій та особистостей, які відрізняються від офіційно затверджених, заборона наукових праць, визнання певних архівних документів екстремістськими матеріалами використовується владою РФ як інструмент запровадження державної монополії на оцінку історичних подій (Гайнутдинов, Чиков, 2019).

Задля практичної реалізації репресивної історичної політики у вересні 2020 року рішенням Голови Слідчого комітету РФ (далі - СК РФ) О. Бастрикіна створено спеціальний підрозділ по розслідуванню злочинів, пов'язаних із «реабілітацією нацизму та фальсифікацією історії Вітчизни», який включено до складу управління по розслідуванню минулих років Головного слідчого управління СК РФ.

Даний підрозділ виконує функцію розслідування «злочинів», які полягають у висловлюванні думок, що не відповідають історичній політиці влади. Крім цього, на даний підрозділ також покладено функції надання «методичної та аналітичної допомоги регіональним слідчим органам» у розслідуванні кримінальних справ щодо «викривлення історії», узагальнення слідчої практики 3 цього напряму та забезпечування «консолідованого правового підходу до оцінки подібних фактів» (B CK создано подразделение по расследованию..., 2020). Фактично, при СК РФ створено підрозділ, який виконує роль координаційного центру у справі провадження репресивної історичної політики РФ. 
Знаковою подією у процесі дослідження російської офіційної історичної політики та стану історичної свідомості сучасного російського суспільства є масштабне дослідження «Яке минуле потрібне майбутньому Росії?», яке було проведено протягом 2016 р. Вільним історичним товариством (російська громадська організація, створена із метою сприяння поширенню наукових уявлень про минуле, а також щодо ролі та завдання історичної науки у житті сучасного суспільства) на замовлення російського Комітету громадянських ініціатив. Як показало проведене дослідження, у сучасній Росії чітко оформлюється дуалістична модель історичної свідомості, яку автори дослідження характеризують як «дві пам'яті». У якості першої, «державницької пам'яті», виступає героїзована версія минулого, що впроваджується через усі можливі канали масової комунікації до суспільної свідомості. «Друга пам'ять» або «локальна пам'ять» («народна пам'ять») є сукупністю форм пам'яті, що через локальну історію родини, міста, регіону поєднують людей із більш широкою спільнотою пам'яті. Наведені дві форми пам'яті існують паралельно та пропонують принципово відмінні методи репрезентації минулого. У ході реалізації історичної політики РФ у рамках першої, «державницької пам'яті», спостерігається стирання меж між історичною роботою та міфотворчістю. Державні чиновники, виступаючи у ролі акторів історичної пам'яті, прямо захищають міфи від історичної критики. Міфи та історичні свідоцтва визнаються рівнозначними, рівноправними елементами історичної пам'яті, при виборі між якими необхідно дотримуватися критерію доцільності. Таким чином, історична істина приводиться у відповідність до домінуючого на даному етапі міфу (Юдин, Хлевнюк, 2017).

Висновки. У сучасній РФ створюється та реалізується жорстка історична політика, завданням якої $є$ формування та трансляція у суспільну свідомість історичного наративу, вигідного владній еліті. У такий спосіб історія з академічної науки перетворюється на засіб політичної боротьби та інструмент «м'якої сили». Дана історична політика має тенденцію до посилення державного керування історичними дослідженнями, контролю над історичною спільнотою, збільшення кримінальної відповідальності за 
будь-які дії у сфері історії (публікація досліджень, висловлювання думок, полеміка), які суперечать історичній політиці влади. Одним із найбільш актуальних елементів цієї історичної політики на даний час $є$ використання іiі у гібридній війні із Україною, що становить істотну загрозу національній безпеці України.

\section{Використані посилання}

Агафонов А. И. (2014) Украина: оценки истории (проблема развития). Технологос. 2014. № 1. С. $14-20$.

Ассман А. (2014). Длинная тень прошлого: мемориальная культура $и$ историческая политика, Москва, Новое литературное обозрение, 238 с.

В СК создано подразделение по расследованию фактов реабилитации наиизма и фальсификаиии истории (2020) URL: https://www.youtube.com/watch?v=yyIvRFCc4Sc [Дата звернення: 22 квітня 2021].

Васильченко В. (2017) Германия после Холокоста. Спор историков и рождение современной Германии. Горький. URL: https://gorky.media/context/germaniya-posle-holokosta/ [Дата звернення: 24 березня 2021].

Гайнутдинов Д., Чиков П. (2019). Россия против Истории. Наказание за пересмотр. Доклад международной Агоры. URL: https://guides.files.bbci.co.uk/bbc-russian/Russia_v_History.pdf [Дата звернення: 30 березня 2021].

Касьянов Г. (2019). Украина и соседи: историческая политика. 1987 2018. Москва, Новое литературное обозрение, 631 с.

Конституиия Российской Федерации (принята на всенародном голосовании 12 декабря 1993 г.) (с поправками). (1993) URL: http://base.garant.ru/10103000/aae119c5fa225c0d54e7c866f74a3548/ [Дата звернення: 27 травня 2021].

Малинова О. Ю. (2012) Использование прошлого в российской официальной исторической политике (на примере анализа ежегодных президентских посланий). Историческая политика в XXI веке: сб. статей. Москва, Новое литературное обозрение, С. 368 - 389.

Малинова О. Ю. (2019) Кто и как формирует официальный исторический нарратив? Анализ российских практик. Полития. № 3 (94) С. 103-126.

Мединский В.Р. (2018) Священные цифры Сталинграда. Российская газета. № 7497 (34).

Миллер А. И. (2009) Россия: власть и история. Pro et Contra. № 3-4 (46). T. 13. C. $6-22$.

Миллер А. И. (2012) Историческая политика в Восточной Европе начала XXI в. Историческая политика в XXI веке: сб. статей. Москва, Новое литературное обозрение, С. 7-32.

О Комиссии при Президенте Российской Федерации по противодействию попьгткам фальсификации истории в ущерб интересам России: Указ Президента Российской Федераџии от 15.05 .2009 2. № 549. (2009). URL: http://www.kremlin.ru/acts/bank/29288 [Дата звернення: 31 березня 2021]. 
Про національну безпеку України: Закон Украӥни від 21.06.2018 № 2469VIII (2018). URL: https://zakon.rada.gov.ua/laws/show/2469-19\#Text [Дата звернення: 25 травня 2021].

Про рішення Ради національної безпеки і оборони України від 14 вересня 2020 року «Про Стратегію національної безпеки Украӥни»: Указ Президента України від 14 вересня 2020 року № 392/2020 (2020). URL: https://www.president.gov.ua/-documents/3922020-35037 [Дата звернення: 25 травня 2021].

Россия и Украина на перекрестках истории: пособие для учителей истории. (2012) Москва, Олма Медиа Групп, 319 с.

Рубцова В.Ю. (2017) Политика памяти в практике конструирования локальной идентичности. Вестник Удмуртского университета. Т.1 вып. 4.451 с.

Руководителям учреждений ОИФН РАН. Распоряжение заместителя академика-секретаря Отделения историко-филологических наук РАН, Руководителя секции истории ОИФН РАН академика В.А.Тишкова от 23.06.2009 № 14100-1255/119 (2009). URL: http://gdb.rferl.org/92BD2F83-749F4B1D-91C8-144DB810E604_mw800_s.jpg [Дата звернення: 31 березня 2021].

Траба Р. (2012) Польские споры об истории в XXI в. Историческая политика в XXI веке: сб. статей. Москва, Новое литературное обозрение, С. 65-102.

Сучасна історична політика Польщі: виклики для Украӥни. Аналітична записка (2017). Національний інститут стратегічних досліджень: URL: http://old2.niss.gov.ua/articles/2528/ [Дата звернення: 25 травня 2021].

Юдин Г.Б., Хлевнюк Д.О. (2017) Какое прошлое нужно будущему России? Краткий аналитический отчет по сочиологическому исследованию в рамках доклада Вольного исторического общества. URL: https://komitetgi.ru/service/ Социология.pdf [Дата звернення: 20 квітня 2021].

Яблонський В.М., Лозовий В.С., Валевський О.Л., Здіорук С.І., Зубченко С.О., Іщенко А.Ю., Карпенко М.М., Литвиненко О.М., Степико М.Т., Токман В.В., Черненко Т.В. Політика історичної пам'яті в контексті національної безпеки України: аналітична доповідь. URL: https://niss.gov.ua/sites/default/files/201909/dopovid_polityka_druk_03.pdf [Дата звернення: 15 червня 2021].

\section{References}

Agafonov A. (2014) Ukraine: assessments of history (development problem). Technologos. 2014. №1. pp. 14-20 (rus).

Assman A. (2014) The Long Shadow of the Past: Memorial Culture and Historical Politics, Moscow, The New Literary Review, 2387 p. (rus).

In the IC, a unit has been created to investigate the facts of the rehabilitation of Nazism and the falsification of history (2020) URL: https://www.youtube.com/watch?v=yyIvRFCc4Sc [Accessed 22 April 2021] (rus).

Vasilchenko V. (2017) Germany after the Holocaust. The controversy of historians and the birth of modern Germany. Gor'kij. URL: https://gorky.media/context/germaniya-posle-holokosta/ [Accessed 24 March 2021] (rus).

Gainutdinov D., Chikov P. Russia against History. Punishment for revision. International Agora Report (2019) URL: https://guides.files.bbci.co.uk/bbc-russian/ Russia_v_History.pdf [Accessed: 30. March 2021) (rus). 
Kasyanov G. (2019) Ukraine and its Neighbors: Historical Politics. 1987-2018. The New Literary Review, Moscow, 631 p. (rus).

Constitution of the Russian Federation (adopted by popular vote on December 12, 1993) (as amended). (1993). URL: http://base.garant.ru/10103000/aae119c5fa225c0d54e7c866f74a3548/ [Accessed: 27 May 2021] (rus).

Malinova O. (2012) Using the past in Russian official historical policy (on the example of the analysis of annual presidential messages). Historical politics in the XXI century: collection of articles, Moscow, The New Literary Review, pp. 368-389 (rus).

Malinova O. (2019) How and who forms the official historical narrative? Analysis of Russian practices. Politia. № 3 (94) pp. 103-126. (rus).

Medinsky V. (2018) Sacred figures of Stalingrad. Russian newspaper. № 7497 (34) (rus).

Miller A. (2009) Russia: Authority and History. Pro et Contra. No. 3-4 (46). Vol. 13 pp. 6-22 (rus).

Miller A. (2012) Historical politics in Eastern Europe at the beginning of XXI century. Historical politics in the XXI century: collection of articles, Moscow, The New Literary Review, pp. 7-32. (rus).

On the Commission under the President of the Russian Federation to counteract attempts to falsify history to the detriment of the interests of Russia: Decree of the President of the Russian Federation of May 15, 2009. № 549. (2009). URL: http://www.kremlin.ru/acts/bank/29288 [Accessed: 31 March 2021] (rus).

About the national security of Ukraine: the Law of Ukraine issued on June 21, 2018 № 2469-VIII (2018). URL: https://zakon.rada.gov.ua/laws/show/2469-19\#Text [Accessed: 25 May 2021] (ukr).

About the decision For the National Security and Defense Council of Ukraine of September 14, 2020 "About the Strategy of the national security of Ukraine»: the Decree of the President of Ukraine of September 14, 2020 №392/2020 (2020). URL: https://www.president.gov.ua/documents/3922020-35037 [Accessed: 25 May 2021] (ukr).

Russia and Ukraine at the crossroads of history: a guide for history teachers. (2012) Moscow Olma Media Group, 319 p. (rus).

Rubtsova V. (2017) Memory politics in the practice of constructing local identity. Bulletin of the Udmurt University. Vol. 1 №. 4.451 p. (rus).

To Heads of institutions of the Department of Physical Sciences of the Russian Academy of Sciences. Order of the Deputy Academician-Secretary of the Department of Historical and Philological Sciences of the Russian Academy of Sciences, Head of the History Section of the Division of Physical Sciences of the Russian Academy of Sciences Academician Tishkov V, dated 23.06.2009 № 141001255/1 19. (2009). URL: http://gdb.rferl.org/92BD2F83-749F-4B1D-91C8144DB810E604_mw800_s.jpg [Accessed: 31 March 2021] (rus)..

Traba R. (2012). Polish history controversy in 21st century Historical politics in XXI century. Historical politics in the XXI century: collection of articles, in Miller A, Lipman M (Ed.). The New Literary Review, Moscow. pp. 65-102 (rus).

Contemporary historical policy of Poland: challenges for Ukraine. Analytical note (2017). National Institute for Strategic Studies: URL: http://old2.niss.gov.ua/articles/2528/ [Accessed: 25 May 2021] (ukr). 
Yudin G., Khlevnyuk D. What past does the future of Russia need?A brief analytical report on sociological research in the framework of the report of the Free Historical Community (2017) 27 p. URL: https://komitetgi.ru/service/ Социология. pdf [Accessed 20 April 2021] (rus).

Yablonsky V., Lozovy V., Valevsky O., Zdioruk S., Zubchenko S., Ishchenko A., Karpenko M., Litvinenko O., Stepyko M., Tokman V. and Chernenko T. (2019). Politics of historical memory in the context of national security of Ukraine: analytical report. URL: https://niss.gov.ua/sites/default/files/2019-09/dopovid_polityka_druk_03. pdf [Accessed: 15 June 2021] (ukr).

\section{Khardel R.}

\section{HISTORICAL POLICY OF THE RUSSIAN FEDERATION AS A THREAT TO THE NATIONAL SECURITY OF UKRAINE}

One of the safest and most effective ways, used by Russian Federation to transmit harmful propaganda, both inside and outside of Ukraine, with intention of igniting public unrest and conflict within the country, is influencing the historical consciousness as a part of mass consciousness, both in context of its own citizens and Ukrainian citizens, as well as the international community. To put this plan into reality, Russian Federation has developed, formed and realized a very aggressive historical doctrine.

Analysis and exposure of this historical doctrine, its final goal, focuses and tasks, as well as its main methods of realization in modern, geopolitical context is one of the top priority tasks to ensure national security of Ukraine. It concerns Ukrainian participation in a prolonged hybrid war, in which Russian Federation actively utilizes political, economic, information's perception psychological, cyber and military methods.

Historic doctrine as a modern phenomenon is a method of ensuring political, cultural, and political or any other loyalty of big social entities, as well as securing ideological and political control over said entities. The most important trait of the historical doctrine is usage of history in internal politics, law practice, and ideological sphere, in diplomatic and military conflicts.

An aggressive historical doctrine is developing in Russian Federation, with only one task - influencing mass consciousness with a historical narrative that is controlled by the ruling Russian elite. This is done with intention of converting history from an academic subject into a "soft force" weapon for the political battlefield. This historical doctrine has a tendency of intensifying governmental control on historical research, controlling the historical community, increasing criminal responsibility for any historical activity that goes against the narrative (publication of scientific research, speaking out publicly, polemics, etc). One of the most currently relevant aspects of this historical doctrine is its' usage in the hybrid war with Ukraine, which is of increasing threat to the national security of Ukraine.

Keywords: national security, historical doctrine, politics of memory, mass consciousness. 